\title{
EFFECT OF ZINC AND IRON FOLIAR APPLICATION WITH TWO LEVELS OF IRRIGATION WATER ACIDITY ON THE QUANTITATIVE AND QUALITATIVE PARAMETERS OF WHEAT (TRITICUM AESTIVUM L.)
}

\author{
ZANDIPOUR, E. ${ }^{1}-$ AJAM NOROZEI, H. ${ }^{1 *}-$ BOSTANI, A. $^{2}$ \\ ${ }^{I}$ Department of Agronomy, Gorgan Branch, Islamic Azad University, Gorgan, Iran \\ ${ }^{2}$ Department of Soil Science, Shahed University, Tehran, Iran \\ *Corresponding author \\ e-mail:ajamnorozei@yahoo.com \\ (Received $18^{\text {th }}$ Nov 2017, Accepted $16^{\text {th }}$ Apr 2018)
}

\begin{abstract}
In addition to enhancing wheat's photosynthesis, growth and ability to cope with stress, the foliar application of zinc and iron can play an effective role in improving consumer nutrition. Therefore, the aim of this study was investigation of zinc and iron foliar application in irrigation water acidity on wheat (Triticum aestivum L.). This experiment was conducted as a triple factorial using a randomized complete blocks design with three replications in Tehran, Iran in 2014-15 and 2015-16. The treatments were two irrigation water acidity $(\mathrm{pH}$ value $=8.14$ and 5$)$, and the foliar application of iron and zinc sulfate $\left(0,2.5\right.$, and $\left.5 \mathrm{~g} \mathrm{~L}^{-1}\right)$. The results revealed that the most grain yield was produced at a $\mathrm{pH}$ value $=5$, with $5 \mathrm{~g} \mathrm{~L}^{-1}$ zinc application. The main cause for increasing the grain yield was enhancement of spike length, tillers and grains per plant. The greatest grain protein content was measured at a $\mathrm{pH}$ value $=5$, with a $5 \mathrm{~g} \mathrm{~L}^{-1}$ zinc application. The maximum grain iron content was calculated at a $\mathrm{pH}$ value $=5$, with 5 $\mathrm{g} \mathrm{L}^{-1}$ zinc usage. The highest grain zinc content was obtained at a $\mathrm{pH}$ value $=5$, with $5 \mathrm{~g} \mathrm{~L}^{-1}$ zinc consumption. The maximum zinc utilization efficiency was observed for the iron control treatment with 5 $\mathrm{g} \mathrm{L}^{-1}$ zinc consumption. Therefore, the treatments that were irrigated with water with an acidic $\mathrm{pH}$ of 5 along with $5 \mathrm{~g} \mathrm{~L}^{-1}$ zinc and iron foliar application had the highest yield and the best qualitative traits.
\end{abstract}

Keywords: grain yield, harvest index, micronutrient nutrition, protein percentage, utilization efficiency

\section{Introduction}

Agricultural production in the twenty-first century has to go along and result in increased food security and it has to be less dependent on fairly rare resources such as agricultural lands, water, fossil fuels, and non-renewable energies (Uphoff, 2012; Pazouki et al., 2017). Wheat crops are grown in a wide range of environments that affect overall performance, particularly grain yield and end-use quality (Yadi et al., 2016). According to the official statistics released by FAO, the wheat cultivation area in the world during the past years has been between 230 million hectares (FAO, 2016). The last set of global statistics showed that the grain yield production was 750 million tons (FAO, 2016). Iran has 6.2 million hectares of wheat field area and 12.3 million tons of wheat production (Ministry of Jihad-e-Agriculture of Iran, 2016).

However, staple grains, such as wheat often contain suboptimal quantities of micronutrients, especially zinc and iron, and most of this content is removed by milling (Borrill et al., 2014). The World Health Organization estimates that approximately $25 \%$ of the world's population suffers from anemia (WHO, 2008); and that iron-deficiency anemia led to the loss of over 46,000 disability-adjusted life years (DALYs) in 2010 alone (Murray and Lopez, 2013). An estimated $17.3 \%$ of people worldwide are at risk of inadequate zinc intake (Wessells and Brown, 2012), and zinc-deficiency leads to the 
estimated annual deaths of 433,000 children under the age of five (WHO, 2009). By taking the geological experiments in Iran into consideration, it becomes clear that $37 \%$ of the lands under irrigated wheat cultivation have problems regarding zinc deficiency (40\%), manganese deficiency (25\%), and supply of copper, which can be absorbed equals 24\% (Ministry of Jihad-e-Agriculture of Iran, 2016). World statistics also show that approximately $50 \%$ and $30 \%$ of the soils under grain cultivation all around the world have problems regarding the deficiency of available zinc and iron, respectively (FAO, 2016).

When nutrition is not properly absorbed in the soil, the foliar application of different elements is an efficient way for solving the problem of the deficiency of these elements (Cakmak, 2008). Based on the studies of many researchers, it was revealed that there are wide variations in grain iron and zinc contents in the wild relatives of modern wheat, and it was found that the contents can significantly exceed those found in modern elite cultivars (Cakmak et al., 2000; Monasterio and Graham, 2000). This natural variation can be utilized for wheat bio-fortification by zinc and iron (Uauy et al., 2006), which was originally identified for increasing the protein content in wild emmer (Triticum turgidum ssp dicoccoides). In isogenic lines, the zinc and iron content of grain increased by 12 and 18\%, respectively (Distelfeld et al., 2007). Zhang et al. (2010) revealed that the iron content of grain had increased significantly from the control treatment to ferric citrate, ferric citrate plus $\mathrm{ZnSO}_{4}$ and $\mathrm{FeSO}_{4}$ application, respectively. Moreover, the grain zinc and the iron content were increased by using zinc and iron fertilizer resources in comparison to the control treatment. Other researchers have shown that micronutrients spraying, particularly zinc, iron, and manganese on leaves, leads to significantly increased wheat grain yield (Wissuwa et al., 2008). Mohammad et al. (2000) reported that zinc and iron application with different methods increased grain yield in comparison to control, and using zinc by the spraying method, maximum grain yield, and zinc concentration were obtained in the grain; using the soil and the spraying method recorded the highest grain yield and grain iron content. Given that micronutrients increase crop production and also influence human well-being and health, one of the simple and economical ways for achieving self-sufficiency and a healthy society is through the addition of micronutrients, especially iron and zinc, to the soil or consuming it through foliar application. In this was, in addition to enhancing the production of crops, the concentration of micronutrients in agricultural crops, including wheat, which is a central part of the food that Iranian people eat, can be increased. By taking into account issues such as the high costs of supplying nutrients from chemical resources, deficiency of nutrients in basic soils, paying attention toward finding an effective and economical method, and replacing the current methods with it with the purpose of fulfilling the needs of agricultural plants, and enriching the diets of humans and animals, seems necessary. Therefore, the aim of this study was to implement the foliar application of zinc and iron in irrigation water with an acidic and a basic $\mathrm{pH}$ value on the yield and the qualitative traits of wheat.

\section{Material and Methods}

\section{Description of the site}

The study was conducted in the University of Shahed, Tehran Province, Iran in 201415 and 2015-16. The experimental farm is geographically situated at $35^{\circ}, 33^{\prime} \mathrm{N}$ latitude, 
and $51^{\circ}, 20^{\prime} \mathrm{E}$ longitude. Tehran is located between mountainous region and plains. Three factors of the Alborz mountain range, the desert, and the western wet winds play an important role in the climate of Tehran. Different weather conditions have been formed in the various regions of Tehran due to its special geographical location. The climate of the Tehran Province is warm and dry in the dry area, cold and semi-humid in the mountain range, and cold with longer winters in high mountains. This experiment was carried out in a warm and dry area. Local weather data during the rice growing period were collected daily from the synoptic meteorological station nearest to the paddy fields (Table 1). In addition, the soil properties at a depth of $0-30 \mathrm{~cm}$ are detailed in Table 2.

Table 1. Description of climatic parameters in the experiment region

\begin{tabular}{c|c|c|c|c|c|c}
\hline Month & Year & $\begin{array}{c}\text { Min. } \\
\text { temp. } \\
\left({ }^{\circ} \mathbf{C}\right)\end{array}$ & $\begin{array}{c}\text { Max. } \\
\text { temp. } \\
\left({ }^{\circ} \mathbf{C}\right)\end{array}$ & $\begin{array}{c}\text { Evaporation } \\
(\mathbf{m m})\end{array}$ & $\begin{array}{c}\text { Rain } \\
(\mathbf{m m})\end{array}$ & $\begin{array}{c}\text { Mean } \\
\text { humidity } \\
(\boldsymbol{\%})\end{array}$ \\
\hline Sep.-Oct. & $2014-15$ & 10.2 & 18.1 & 78.2 & 28.9 & 65 \\
& $2015-16$ & 9.6 & 19.3 & 81.6 & 44.6 & 70 \\
Oct.-Nov. & $2014-15$ & 10.5 & 20.1 & 54.4 & 65.6 & 72 \\
& $2015-16$ & 10 & 19.1 & 49.2 & 54.8 & 68 \\
Nov.-Dec. & $2014-15$ & 5.4 & 16.3 & 15.1 & 69 & 62 \\
& $2015-16$ & 2.5 & 10.1 & 13.2 & 57 & 71 \\
Dec.-Jan. & $2014-15$ & 4.2 & 11.5 & 8.1 & 78 & 63 \\
& $2015-16$ & 3.1 & 13.2 & 12.1 & 18 & 72 \\
Jan.-Feb. & $2014-15$ & 1.2 & 8.6 & 14.3 & 48 & 58 \\
& $2015-16$ & 0 & 11.1 & 25.8 & 36 & 50 \\
March.-Apr. & $2014-15$ & 4.5 & 12.2 & 32.5 & 18 & 55 \\
& $2015-16$ & 3.3 & 12 & 39.2 & 15 & 71 \\
Apr.-May & $2014-15$ & 6.9 & 16.3 & 65.8 & 38 & 65 \\
& $2015-16$ & 6 & 15.1 & 58.2 & 25 & 66 \\
May-Jun. & $2014-15$ & 18.1 & 24.1 & 98.3 & 12 & 57 \\
& $2015-16$ & 20.2 & 25.1 & 108.6 & 14 & 56 \\
Jun.-Jul. & $2014-15$ & 18.1 & 25 & 125.6 & 8 & 63 \\
\hline
\end{tabular}

Table 2. Soil properties of experiment site in Tehran region

\begin{tabular}{c|c|c|c|c|c|c|c|c|c}
\hline $\begin{array}{c}\text { Depth } \\
(\mathbf{c m})\end{array}$ & $\begin{array}{c}\text { Soil } \\
\text { texture }\end{array}$ & $\begin{array}{c}\text { EC } \\
(\mathbf{d S} \\
\left.\mathbf{m}^{-1}\right)\end{array}$ & $\begin{array}{c}\mathbf{C E C} \\
(\boldsymbol{\%})\end{array}$ & $\mathbf{p H}$ & $\begin{array}{c}\text { Organic } \\
\text { carbon } \\
(\boldsymbol{\%})\end{array}$ & $\begin{array}{c}\text { Phosphorus } \\
\text { availability } \\
(\mathbf{m g ~ k g} \mathbf{~})\end{array}$ & $\begin{array}{c}\text { Potassium } \\
\text { availability } \\
\left(\mathbf{m g ~ k g}^{-1}\right)\end{array}$ & $\begin{array}{c}\text { Iron } \\
\text { availability } \\
\left(\mathbf{m g ~ k g}^{-1}\right)\end{array}$ & $\begin{array}{c}\text { Zinc } \\
\text { availability } \\
\left(\mathbf{m g ~ k g}^{-1}\right)\end{array}$ \\
\hline $0-30$ & $\begin{array}{c}\text { Sandy } \\
\text { loam }\end{array}$ & 3.8 & 11.5 & 7.8 & 0.52 & 13 & 159 & 2.78 & 4.8 \\
\hline
\end{tabular}

\section{Description of the experiment}

The investigated wheat cultivar in this experiment was Pishtaz. This experiment was conducted as a triple factorial using a randomized complete blocks design with three replications. The treatments were as follows: two irrigation water acidity (water of the area with a $\mathrm{pH}$ value $=8.14$ and water with a $\mathrm{pH}$ value $=5$, which were created by sulfuric acid), and the foliar application of iron sulfate fertilizer $\left(0,2.5\right.$, and $\left.5 \mathrm{gr} \mathrm{L}^{-1}\right)$, and zinc sulfate fertilizer $\left(0,2.5\right.$, and $\left.5 \mathrm{gr} \mathrm{L}^{-1}\right)$.

Nitrogen, phosphorus, and potassium were added to the soil based on the soil test. In terms of fertilizer application, a basal dose of $75 \mathrm{~kg} \mathrm{P}_{2} \mathrm{O}_{5} \mathrm{ha}^{-1}$ was applied in the form of 
triple super phosphate. Nitrogen was applied in the form of urea $\left(115 \mathrm{~kg} \mathrm{~N} \mathrm{ha}^{-1}\right)$. Potassium was applied in the form of potassium sulfate $\left(75 \mathrm{~kg} \mathrm{~K}_{2} \mathrm{O}\right.$ ha $\left.{ }^{-1}\right)$. Phosphorus and potassium were applied as basal dressing. Nitrogen application was split: $20 \%$ at planting stage, $25 \%$ of top-dressed at the early tillering stage, and $25 \%$ of nitrogen was applied at the booting stage. The planting row spaces were $12 \times 2 \mathrm{~cm}^{2}$ at a seed rate of $250 \mathrm{~kg}$ per hectare. Standard agronomic practices were followed throughout the growing season. It is necessary to note that the experimental site was used for wheat and corn cultivation in the previous crop year. To control the weeds, herbicide Topic was applied at 1 litre per hectare, once on narrow leaf weeds, and simultaneously, herbicide Granestar was applied at 25 gram per hectare on wide leaf weeds. The protection operation for fighting pests and diseases was performed according to the recommendations of the region.

\section{Evaluation traits}

\section{Quantitative parameters}

During the growth period, after the removal of marginal effects in each site, traits were randomly measured according to the standard evaluation system. Thus, 10 plants were randomly selected from each experimental plot and their average was analyzed.

Data on agronomical traits such as spike length, number of tillers per plant, number of grains per plant, grain yield, and harvest index were recorded. Tillers per plant were reordered by counting the number of tillers per plant in each experimental plot. Grain yield in each experimental plot was determined at the physiologically matured stage and then converted into $\mathrm{kg} \mathrm{ha}^{-1}$.

\section{Qualitative parameters}

The dry digestion method was used for measuring the zinc and the iron in the plant samples. The dried plant samples were crushed and made into powder at $70^{\circ} \mathrm{C}$ so that they would pass through a 20 -mesh sieve (of 0.86 centimeter diameter). Moreover, in order to measure the protein content of the grain, the micro Kjeldahl method was used and nitrogen was measured, and by multiplying the amount of nitrogen by 5.7, protein content was calculated. The protein content per hectare was calculated from the product of the protein percentage multiplied by grain yield (Martre et al., 2003; Samonte et al., 2006). To determine the qualitative properties related to the iron and the zinc elements, the following instructions were applied (Dobermann, 2005; Fan et al., 2004).

Iron and zinc uptake by the grain was achieved by the element content in the grain multiplied by the grain yield. The iron and zinc uptake by straw (stem and leaf) was achieved by the element content in the straw (stem and leaf) multiplied by straw yield. The efficiency utilization of the elements was calculated from the ratio of grain weight to the amount of the absorbed element by the plant. This index was expressed in kilograms per kilogram. By determining the amount of iron and zinc uptake by grain and shoot, the harvest index was calculated through the amount of element absorbed by the grain to the total amount of absorbed element, which are expressed as percentages.

\section{Statistical analysis}

After normalization and the Kaiser-Meyer-Olkin (KMO) test, the data analyzed by the statistical analysis software (SAS) and the comparison of averages were calculated by least significant differences (LSD) tests at a $5 \%$ probability level. 


\section{Results}

In order to evaluate the studied traits in the experiment, the obtained data were analyzed using the variance homogeneity test by the Bartlett method. The results showed that the traits were not significant in Bartlett's test. Therefore, data analysis was performed based on compound analysis.

\section{Quantitative parameters}

Data concerning quantitative parameters is presented in Table 3. The combined statistical analysis of the data revealed that all the quantitative parameters (spike length, number of tillers per hill, number of grains per plant, grain yield, and harvest index) were significantly statistically $(\mathrm{P} \leq 0.01 ; 0.05)$ affected by water acidity $(\mathrm{pH})$ and iron (Fe) foliar application; furthermore, except for the harvest index, all the quantitative parameters were significant statistically $(\mathrm{P} \leq 0.01)$ on zinc $(\mathrm{Zn})$ treatment and plant height, spike length, the number of tillers and grains per plant, and grain yield were significant at the $1 \%$ probability level under the effect of the year (Table 3). At double interaction of year and water acidity, spike length, and the number of tillers per plant were significant statistically at the $1 \%$ and the $5 \%$ probability level.

Table 3. Compound mean square of quantitative traits of wheat under $p H$ of water, iron and zinc fertilizer treatment

\begin{tabular}{|c|c|c|c|c|c|c|}
\hline S.O.V. & DF & $\begin{array}{l}\text { Spike } \\
\text { length }\end{array}$ & $\begin{array}{c}\text { Number of tiller per } \\
\text { plant }\end{array}$ & $\begin{array}{c}\text { Number of grain per } \\
\text { plant }\end{array}$ & Grain yield & $\begin{array}{c}\text { Harvest } \\
\text { index }\end{array}$ \\
\hline Year $(\mathrm{Y})$ & 1 & $9.94^{* *}$ & $1.52^{* * *}$ & $2034.68^{* *}$ & $4039352.40^{* * *}$ & $0.26^{\mathrm{ns}}$ \\
\hline $\mathrm{Y}(\mathrm{R})$ & 4 & 0.86 & 1.22 & 442.61 & 562159.80 & 5.31 \\
\hline $\mathrm{pH}(\mathrm{P})$ & 1 & $30.12^{* *}$ & $5.16^{* *}$ & $1885.26^{* *}$ & $11368403.56^{* *}$ & $42.10^{*}$ \\
\hline Iron $(\mathrm{F})$ & 2 & $10.04^{* * *}$ & $2.21^{* *}$ & $733.65^{\text {*** }}$ & $38575517.38^{\text {*** }}$ & $598.93^{* *}$ \\
\hline Zinc (Z) & 2 & $2.05^{* *}$ & $0.50^{\text {** }}$ & $193.63^{* * *}$ & $2749586.78^{* *}$ & $18.45^{\mathrm{ns}}$ \\
\hline $\mathrm{Y} \times \mathrm{P}$ & 1 & $0.68^{* * *}$ & $0.04^{*}$ & $0.02^{\mathrm{ns}}$ & $172688.02^{\mathrm{ns}}$ & $22.50^{\mathrm{ns}}$ \\
\hline $\mathrm{Y} \times \mathrm{F}$ & 2 & $0.02^{\text {ns }}$ & $0.005^{\mathrm{ns}}$ & $2.54^{\mathrm{ns}}$ & $302234.81^{\mathrm{ns}}$ & $5.06^{\mathrm{ns}}$ \\
\hline $\mathrm{Y} \times \mathrm{Z}$ & 2 & $0.01^{\mathrm{ns}}$ & $0.007^{\mathrm{ns}}$ & $0.80^{\mathrm{ns}}$ & $45581.84^{\mathrm{ns}}$ & $2.79^{\mathrm{ns}}$ \\
\hline $\mathrm{P} \times \mathrm{F}$ & 2 & $0.26^{* *}$ & $0.06^{* * *}$ & $1.43^{\mathrm{ns}}$ & $4183529.95^{* *}$ & $217.80^{* *}$ \\
\hline$P \times Z$ & 2 & $0.21^{*}$ & $0.003^{\mathrm{ns}}$ & $2.72^{\mathrm{ns}}$ & $70537.00^{\mathrm{ns}}$ & $7.41^{\mathrm{ns}}$ \\
\hline $\mathrm{F} \times \mathrm{Z}$ & 4 & $0.03^{\text {ns }}$ & $0.01^{\mathrm{ns}}$ & $2.80^{\mathrm{ns}}$ & $16411.09^{\text {ns }}$ & $4.15^{\mathrm{ns}}$ \\
\hline $\mathrm{Y} \times \mathrm{P} \times \mathrm{F}$ & 2 & $0.003^{\mathrm{ns}}$ & $0.001^{\mathrm{ns}}$ & $2.59^{\mathrm{ns}}$ & $212483.79^{\mathrm{ns}}$ & $23.19^{\text {ns }}$ \\
\hline $\mathrm{Y} \times \mathrm{P} \times \mathrm{Z}$ & 2 & $0.008^{\mathrm{ns}}$ & $0.0004^{\mathrm{ns}}$ & $0.51^{\mathrm{ns}}$ & $15786.14^{\mathrm{ns}}$ & $0.01^{\mathrm{ns}}$ \\
\hline $\mathrm{Y} \times \mathrm{F} \times \mathrm{Z}$ & 4 & $0.03^{\text {ns }}$ & $0.001^{\mathrm{ns}}$ & $0.03^{\mathrm{ns}}$ & $4382.00^{\mathrm{ns}}$ & $0.66^{\mathrm{ns}}$ \\
\hline $\mathrm{P} \times \mathrm{F} \times \mathrm{Z}$ & 4 & $0.04^{\mathrm{ns}}$ & $0.01^{\mathrm{ns}}$ & $7.32^{*}$ & $47437.17^{\mathrm{ns}}$ & $12.10^{\mathrm{ns}}$ \\
\hline $\mathrm{Y} \times \mathrm{P} \times \mathrm{F} \times \mathrm{Z}$ & 4 & $0.004^{\mathrm{ns}}$ & $0.0002^{\mathrm{ns}}$ & $0.14^{\mathrm{ns}}$ & $12917.94^{\mathrm{ns}}$ & $3.72^{\mathrm{ns}}$ \\
\hline Error & 68 & 0.04 & 0.01 & 2.37 & 157858.10 & 14.91 \\
\hline C.V. (\%) & - & 3.19 & 3.09 & 2.70 & 8.84 & 9.75 \\
\hline
\end{tabular}

$\mathrm{ns}, *$ and $* *$ : non significant and significant in $5 \%$ and $1 \%$ probability level, respectively

Moreover, spike length, the number of tillers per plant, grain yield, and harvest index were significant at the $1 \%$ probability level under the interaction of water acidity and iron (Fe). Only the spike length was significant at the 5\% probability level under the interaction of water acidity and the zinc fertilizer (Table 3). A mean comparison showed that the at the $\mathrm{P} \times \mathrm{F}$ interaction, the greatest spike length was obtained at a $\mathrm{pH}$ value $=5$ for 2.5 and $5 \mathrm{~g} \mathrm{~L}^{-1}$ iron (7.14 and $7.45 \mathrm{~cm}$, respectively). The lowest spike length (5.35 $\mathrm{cm}$ ) was obtained at a $\mathrm{pH}$ value $=8.14$ and iron control treatment (Table 4). 
Table 4. Double interaction $\mathrm{pH}$ of water and iron fertilizer application on quantitative traits of wheat

\begin{tabular}{c|c|c|c|c}
\hline Interaction & $\begin{array}{c}\text { Spike length } \\
(\mathbf{c m})\end{array}$ & Number of tiller per plant & $\begin{array}{c}\text { Grain yield } \\
\left(\mathbf{k g ~ h a}^{-1}\right)\end{array}$ & $\begin{array}{c}\text { Harvest index } \\
(\mathbf{\%})\end{array}$ \\
\hline $\mathrm{P}_{1} \mathrm{~F}_{1}$ & $5.35 \mathrm{c}$ & $2.40 \mathrm{c}$ & $3509 \mathrm{e}$ & $38.72 \mathrm{~b}$ \\
$\mathrm{P}_{1} \mathrm{~F}_{2}$ & $6.08 \mathrm{ab}$ & $2.63 \mathrm{bc}$ & $4009 \mathrm{~d}$ & $38.77 \mathrm{~b}$ \\
$\mathrm{P}_{1} \mathrm{~F}_{3}$ & $6.56 \mathrm{~b}$ & $2.82 \mathrm{~b}$ & $4999 \mathrm{c}$ & $43.12 \mathrm{a}$ \\
$\mathrm{P}_{2} \mathrm{~F}_{1}$ & $6.58 \mathrm{~b}$ & $2.75 \mathrm{~b}$ & $3371 \mathrm{f}$ & $31.89 \mathrm{c}$ \\
$\mathrm{P}_{2} \mathrm{~F}_{2}$ & $7.14 \mathrm{a}$ & $3.08 \mathrm{ab}$ & $5074 \mathrm{~b}$ & $41.24 \mathrm{ab}$ \\
$\mathrm{P}_{2} \mathrm{~F}_{3}$ & $7.45 \mathrm{a}$ & $3.32 \mathrm{a}$ & $6018 \mathrm{a}$ & $43.73 \mathrm{a}$ \\
\hline
\end{tabular}

*: Values within a column followed by same letter are not significantly different at LSD ( $\mathrm{P} \leq 0.05)$

* $\mathrm{P}_{1}$ and $\mathrm{P}_{2}$ are $\mathrm{pH}$ of irrigation water including 8.14 and 5 respectively

$\mathrm{F}_{1}, \mathrm{~F}_{2}$ and $\mathrm{F}_{3}$ are iron fertilizer including $0,2.5$ and $5 \mathrm{~g} \mathrm{~L}^{-1}$ respectively

With attention to the interaction of water acidity and zinc fertilizer, it was found that the maximum spike length was produced at a $\mathrm{pH}$ value $=5$ with 2.5 and $5 \mathrm{~g} \mathrm{~L}^{-1}$ zinc application. The minimum spike length had been observed at a $\mathrm{pH}$ value $=8.14$ with control treatment and $2 \mathrm{~g} \mathrm{~L}^{-1} \mathrm{Zn}$ usage (Table 5).

Table 5. Double interaction of $\mathrm{pH}$ of water and zinc fertilizer on qualitative and quantitative parameters of wheat

\begin{tabular}{|c|c|c|c|c|}
\hline Interaction & $\begin{array}{l}\text { Spike length } \\
\text { (cm) }\end{array}$ & $\begin{array}{c}\text { Grain protein content } \\
(\%)\end{array}$ & $\begin{array}{c}\text { Protein } \\
\text { yield }\left(\mathrm{kg} \mathrm{ha}^{-1}\right)\end{array}$ & $\begin{array}{c}\text { Grain zinc } \\
\text { uptake }\left(\mathrm{kg} \mathrm{ha}^{-1}\right)\end{array}$ \\
\hline $\mathrm{P}_{1} \mathrm{Z}_{1}$ & $5.71 \mathrm{c}$ & $8.49 \mathrm{c}$ & $335.35 \mathrm{e}$ & $38.58 \mathrm{~d}$ \\
\hline $\mathrm{P}_{1} \mathrm{Z}_{2}$ & $5.96 \mathrm{c}$ & $8.86 \mathrm{bc}$ & $370.88 \mathrm{~d}$ & $82.21 \mathrm{c}$ \\
\hline $\mathrm{P}_{1} \mathrm{Z}_{3}$ & $6.33 a b c$ & $9.24 a b c$ & $408.24 \mathrm{~cd}$ & $113.49 \mathrm{bc}$ \\
\hline $\mathrm{P}_{2} \mathrm{Z}_{1}$ & $6.89 \mathrm{ab}$ & $10.43 \mathrm{ab}$ & $473.50 \mathrm{c}$ & $61.35 \mathrm{~cd}$ \\
\hline $\mathrm{P}_{2} \mathrm{Z}_{2}$ & $7.06 \mathrm{a}$ & $11.06 \mathrm{a}$ & $538.28 \mathrm{ab}$ & $135.30 \mathrm{~b}$ \\
\hline $\mathrm{P}_{2} \mathrm{Z}_{3}$ & $7.22 \mathrm{a}$ & $11.50 \mathrm{a}$ & $596.10 \mathrm{a}$ & $190.94 \mathrm{a}$ \\
\hline
\end{tabular}

*: Values within a column followed by same letter are not significantly different at LSD ( $\mathrm{P} \leq 0.05)$

* $\mathrm{P}_{1}$ and $\mathrm{P}_{2}$ are $\mathrm{pH}$ of irrigation water including 8.14 and 5 respectively

$Z_{1}, Z_{2}$ and $Z_{3}$ are zinc fertilizer including $0,2.5$ and $5 \mathrm{~g} \mathrm{~L}^{-1}$ respectively

With regard to the mean comparison results, with $5 \mathrm{~g} \mathrm{~L}^{-1}$ zinc fertilizer application, the number of tillers per plant was increased compared to 0 and $2.5 \mathrm{~g} \mathrm{~L}^{-1}$ zinc application (Table 6). In terms of the double interaction of the year and the water acidity, it was found that the maximum number of tillers per plant (3.19 tillers) was obtained in the first year for a $\mathrm{pH}$ value $=5$. The minimum number of tillers per plant ( 2.51 tillers) was obtained in the second year for a $\mathrm{pH}$ value $=8.14$ (Table 7). Moreover, at the double interaction of water acidity and the iron $(\mathrm{Fe})$ fertilizer, the most tillers per plant (3.32 tillers) was obtained for a $\mathrm{pH}$ value $=5$, with $5 \mathrm{~m} \mathrm{~L}^{-1}$ iron application. The minimum tillers per plant (2.40 tillers) was produced at a $\mathrm{pH}$ value $=8.14$ and a control treatment (Table 4). At the triple interaction of water acidity, and iron $(\mathrm{Fe})$ and zinc (Zn) application, the highest number of grains per plant was observed for $\mathrm{P}_{2} \mathrm{~F}_{2} \mathrm{Z}_{3}$ (64.68 grains) and at a $\mathrm{pH}$ value $=5$, with $5 \mathrm{~g} \mathrm{~L}^{-1}$ of iron consumption, and all three zinc fertilizer levels equaling 63.51, 65.37, and 67.56 grains, respectively (Table 8). 
Table 6. Mean comparison quantitative traits of wheat under $p H$ of water, iron and zinc fertilizer treatment

\begin{tabular}{|c|c|c|c|c|c|}
\hline Treatment & $\begin{array}{c}\text { Spike } \\
\text { length }(\mathrm{cm})\end{array}$ & $\begin{array}{c}\text { Number of tiller } \\
\text { per plant }\end{array}$ & $\begin{array}{c}\text { Number of grain } \\
\text { per plant }\end{array}$ & $\begin{array}{l}\text { Grain yield } \\
\left(\mathrm{kg} \mathrm{ha}^{-1}\right)\end{array}$ & $\begin{array}{c}\text { Harvest } \\
\text { index } \\
(\%)\end{array}$ \\
\hline Year & & & & & \\
\hline 2014-15 & $6.83 \mathrm{a}$ & $2.95 \mathrm{a}$ & $61.36 \mathrm{a}$ & $4690 \mathrm{a}$ & $39.63 \mathrm{a}$ \\
\hline $2015-16$ & $6.23 \mathrm{~b}$ & $2.71 \mathrm{~b}$ & $52.68 \mathrm{~b}$ & $4303 \mathrm{~b}$ & $39.53 \mathrm{a}$ \\
\hline LSD 0.05 & 0.08 & 0.03 & 0.59 & 152.58 & 1.48 \\
\hline $\mathrm{pH}$ & & & & & \\
\hline 8.14 & $6.00 \mathrm{~b}$ & $2.61 \mathrm{~b}$ & $52.84 \mathrm{~b}$ & $4172 \mathrm{~b}$ & $40.20 \mathrm{a}$ \\
\hline 5 & $7.06 \mathrm{a}$ & $3.05 \mathrm{a}$ & $61.19 \mathrm{a}$ & $4821 \mathrm{a}$ & $38.96 \mathrm{a}$ \\
\hline LSD 0.05 & 0.08 & 0.03 & 0.59 & 152.58 & 1.48 \\
\hline $\mathrm{Fe}$ & & & & & \\
\hline 0 & $5.96 \mathrm{c}$ & $2.58 \mathrm{c}$ & $52.28 \mathrm{c}$ & $3440 \mathrm{c}$ & $35.30 \mathrm{c}$ \\
\hline $2.5 \mathrm{~g} \mathrm{~L}^{-1}$ & $6.61 \mathrm{~b}$ & $2.86 \mathrm{~b}$ & $57.50 \mathrm{~b}$ & $4542 \mathrm{~b}$ & $40.01 \mathrm{~b}$ \\
\hline $5 \mathrm{~g} \mathrm{~L}^{-1}$ & $7.01 \mathrm{a}$ & $3.07 \mathrm{a}$ & $61.27 \mathrm{a}$ & $5508 \mathrm{a}$ & $43.43 \mathrm{a}$ \\
\hline LSD 0.05 & 0.10 & 0.04 & 0.72 & 186.87 & 1.82 \\
\hline $\mathrm{Zn}$ & & & & & \\
\hline 0 & $6.30 \mathrm{c}$ & $2.71 \mathrm{c}$ & $54.49 \mathrm{c}$ & $4220 \mathrm{c}$ & $38.80 \mathrm{a}$ \\
\hline $2.5 \mathrm{~g} \mathrm{~L}^{-1}$ & $6.51 \mathrm{~b}$ & $2.86 \mathrm{~b}$ & $57.52 \mathrm{~b}$ & $4497 \mathrm{~b}$ & $39.74 \mathrm{a}$ \\
\hline $5 \mathrm{~g} \mathrm{~L}^{-1}$ & $6.78 \mathrm{a}$ & $2.94 \mathrm{a}$ & $59.04 \mathrm{a}$ & $4772 \mathrm{a}$ & $40.20 \mathrm{a}$ \\
\hline LSD 0.05 & 0.10 & 0.04 & 0.72 & 186.87 & 1.82 \\
\hline
\end{tabular}

*: Values within a column followed by same letter are not significantly different at $\mathrm{LSD}(\mathrm{P} \leq 0.05)$

Table 7. Double interaction of year and $\mathrm{pH}$ of water on qualitative and quantitative parameters of wheat

\begin{tabular}{l|c|c|c|c|c|c}
\hline Interaction & $\begin{array}{c}\text { Spike } \\
\text { length } \\
(\mathbf{c m})\end{array}$ & $\begin{array}{c}\text { Number of } \\
\text { tiller per } \\
\text { plant }\end{array}$ & $\begin{array}{c}\text { Iron utilization } \\
\text { efficiency } \\
\left(\mathbf{k g ~ k g}^{-1}\right)\end{array}$ & $\begin{array}{c}\text { Iron harvest } \\
\text { index } \\
(\mathbf{\%})\end{array}$ & $\begin{array}{c}\text { Straw zinc } \\
\text { content } \\
(\mathbf{\%})\end{array}$ & $\begin{array}{c}\text { Zinc } \\
\text { harvest } \\
\text { index } \\
(\boldsymbol{\%})\end{array}$ \\
\hline $\mathrm{Y}_{1} \mathrm{P}_{1}$ & $6.38 \mathrm{ab}$ & $2.71 \mathrm{ab}$ & $18.91 \mathrm{~b}$ & $61.71 \mathrm{a}$ & $14.27 \mathrm{ab}$ & $56.06 \mathrm{a}$ \\
$\mathrm{Y}_{1} \mathrm{P}_{2}$ & $7.28 \mathrm{a}$ & $3.19 \mathrm{a}$ & $10.21 \mathrm{c}$ & $63.69 \mathrm{a}$ & $18.12 \mathrm{a}$ & $58.36 \mathrm{a}$ \\
$\mathrm{Y}_{2} \mathrm{P}_{1}$ & $5.62 \mathrm{~b}$ & $2.51 \mathrm{~b}$ & $23.12 \mathrm{a}$ & $62.47 \mathrm{a}$ & $11.69 \mathrm{~b}$ & $57.39 \mathrm{a}$ \\
$\mathrm{Y}_{2} \mathrm{P}_{2}$ & $6.83 \mathrm{a}$ & $2.91 \mathrm{ab}$ & $10.32 \mathrm{c}$ & $62.45 \mathrm{a}$ & $18.18 \mathrm{a}$ & $55.64 \mathrm{a}$ \\
\hline
\end{tabular}

*: Values within a column followed by same letter are not significantly different at $\mathrm{LSD}(\mathrm{P} \leq 0.05)$

$Y_{1}$ and $Y_{2}$ are experiment period including 2014-15 and 2015-16 years respectively

* $\mathrm{P}_{1}$ and $\mathrm{P}_{2}$ are $\mathrm{pH}$ of irrigation water including 8.14 and 5 respectively

The mean comparison shows that with $5 \mathrm{~g} \mathrm{~L}^{-1}$ zinc foliar application, the grain yield was enhanced to 13.08 and $6.12 \%$ in comparison to 0 and $2.5 \mathrm{~g} \mathrm{~L}^{-1}$, respectively. The main cause for increasing the grain yield in the $5 \mathrm{~g} \mathrm{~L}^{-1}$ zinc foliar application involved the enhancement of spike length, and the number of tillers and grains per plant in this treatment (Table 6 ). At the double interaction of water acidity and iron consumption, it was found that the most grain yield $\left(6,018 \mathrm{~kg} \mathrm{ha}^{-1}\right)$ was produced at a $\mathrm{pH}$ value $=5$, with $5 \mathrm{~g} \mathrm{~L}^{-1}$ zinc foliar application. The least grain yield $\left(3,371 \mathrm{~kg} \mathrm{ha}^{-1}\right)$ was obtained at a $\mathrm{pH}$ value $=5$ and control treatment (Table 4). Moreover, at water acidity and iron interaction, the highest harvest index was observed at both $\mathrm{pH}$ levels, with $5 \mathrm{~g} \mathrm{~L}^{-1}$ iron foliar application (43.12\% and $43.73 \%$, respectively). The least harvest index $(31.89 \%)$ was calculated at $\mathrm{pH}$ value $=5$ and the control iron treatment (Table 4). 
Table 8. Triple interaction $\mathrm{pH}$ of water, iron and zinc fertilizers on grain per plant and iron harvest index of wheat

\begin{tabular}{c|c|c}
\hline Interaction & Number of grain per plant & Iron harvest index (\%) \\
\hline $\mathrm{P}_{1} \mathrm{~F}_{1} \mathrm{Z}_{1}$ & $46.27 \mathrm{c}$ & $57.82 \mathrm{~b}$ \\
$\mathrm{P}_{1} \mathrm{~F}_{1} \mathrm{Z}_{2}$ & $48.75 \mathrm{bc}$ & $54.12 \mathrm{bc}$ \\
$\mathrm{P}_{1} \mathrm{~F}_{1} \mathrm{Z}_{3}$ & $49.92 \mathrm{bc}$ & $52.23 \mathrm{c}$ \\
$\mathrm{P}_{1} \mathrm{~F}_{2} \mathrm{Z}_{1}$ & $51.63 \mathrm{abc}$ & $63.80 \mathrm{ab}$ \\
$\mathrm{P}_{1} \mathrm{~F}_{2} \mathrm{Z}_{2}$ & $52.81 \mathrm{abc}$ & $64.69 \mathrm{ab}$ \\
$\mathrm{P}_{1} \mathrm{~F}_{2} \mathrm{Z}_{3}$ & $54.97 \mathrm{abc}$ & $62.77 \mathrm{ab}$ \\
$\mathrm{P}_{1} \mathrm{~F}_{3} \mathrm{Z}_{1}$ & $53.57 \mathrm{abc}$ & $67.54 \mathrm{a}$ \\
$\mathrm{P}_{1} \mathrm{~F}_{3} \mathrm{Z}_{2}$ & $58.87 \mathrm{ab}$ & $66.57 \mathrm{a}$ \\
$\mathrm{P}_{1} \mathrm{~F}_{3} \mathrm{Z}_{3}$ & $58.75 \mathrm{ab}$ & $69.24 \mathrm{a}$ \\
$\mathrm{P}_{2} \mathrm{~F}_{1} \mathrm{Z}_{1}$ & $52.95 \mathrm{abc}$ & $62.22 \mathrm{ab}$ \\
$\mathrm{P}_{2} \mathrm{~F}_{1} \mathrm{Z}_{2}$ & $57.43 \mathrm{ab}$ & $62.07 \mathrm{ab}$ \\
$\mathrm{P}_{2} \mathrm{~F}_{1} \mathrm{Z}_{3}$ & $58.36 \mathrm{ab}$ & $61.59 \mathrm{ab}$ \\
$\mathrm{P}_{2} \mathrm{~F}_{2} \mathrm{Z}_{1}$ & $58.98 \mathrm{ab}$ & $62.86 \mathrm{ab}$ \\
$\mathrm{P}_{2} \mathrm{~F}_{2} \mathrm{Z}_{2}$ & $61.91 \mathrm{ab}$ & $61.96 \mathrm{ab}$ \\
$\mathrm{P}_{2} \mathrm{~F}_{2} \mathrm{Z}_{3}$ & $64.68 \mathrm{a}$ & $62.14 \mathrm{ab}$ \\
$\mathrm{P}_{2} \mathrm{~F}_{3} \mathrm{Z}_{1}$ & $63.51 \mathrm{a}$ & $64.43 \mathrm{ab}$ \\
$\mathrm{P}_{2} \mathrm{~F}_{3} \mathrm{Z}_{2}$ & $65.37 \mathrm{a}$ & $65.46 \mathrm{ab}$ \\
$\mathrm{P}_{2} \mathrm{~F}_{3} \mathrm{Z}_{3}$ & $67.56 \mathrm{a}$ & $64.90 \mathrm{ab}$ \\
\hline
\end{tabular}

*: Values within a column followed by same letter are not significantly different at $\mathrm{LSD}(\mathrm{P} \leq 0.05)$

* $\mathrm{P}_{1}$ and $\mathrm{P}_{2}$ are $\mathrm{pH}$ of irrigation water including 8.14 and 5 respectively

$\mathrm{F}_{1}, \mathrm{~F}_{2}$ and $\mathrm{F}_{3}$ are iron fertilizer including $0,2.5$ and $5 \mathrm{~g} \mathrm{~L}^{-1}$ respectively

$\mathrm{Z}_{1}, \mathrm{Z}_{2}$ and $\mathrm{Z}_{3}$ are zinc fertilizer including $0,2.5$ and $5 \mathrm{~g} \mathrm{~L}^{-1}$ respectively

\section{Qualitative parameters}

The combined variance analysis of the qualitative parameters indicated that all qualitative parameters except the zinc harvest index showed a significant difference under the effect of water acidity ( $\mathrm{pH}$ value) and iron (Fe) for foliar application in $1 \%$ and 5\% probability levels, respectively (Table 9). Moreover, some qualitative parameters including grain protein content, protein yield, grain iron uptake, grain and straw zinc uptake, zinc utilization efficiency, and zinc harvest index had significant differences $(\mathrm{P} \leq 0.01)$ under the effect of zinc $(\mathrm{Zn})$ foliar application. In addition, all the qualitative parameters, except iron harvest index, zinc utilization efficiency, and zinc harvest index, were significant at the $1 \%$ probability level on year effect (Table 9). At the double interaction of year and water acidity straw iron content, the iron utilization efficiency and the harvest index, and the straw zinc content and the zinc harvest index were statistically significant. Moreover, at year and iron double interaction, protein yield, grain iron uptake, and grain zinc uptake were significant statistically (Table 9). At the interaction of year and zinc foliar application, only the grain zinc uptake was significant statistically with a $1 \%$ probability level. In addition, at the double interaction of water acidity and iron fertilizer grain protein content, the protein yield, grain iron uptake, iron utilization efficiency, iron harvest index, grain zinc uptake, zinc utilization efficiency, and zinc harvest index were significant statistically at a $1 \%$ probability level (Table 9). At the double interaction of water acidity and zinc foliar application, it was found that the grain protein content, protein yield, and the grain zinc uptake were significant statistically. In iron and zinc double interaction, certain parameters, including iron harvest index, grain zinc uptake, zinc utilization efficiency, and zinc harvest index showed significant differences in the $1 \%$ and the $5 \%$ probability levels. 
Table 9. Compound mean square of quantitative traits of wheat under $p H$ of water, iron and zinc fertilizers treatment

\begin{tabular}{|c|c|c|c|c|c|c|c|c|c|}
\hline S.O.V. & DF & $\begin{array}{l}\text { Grain } \\
\text { protein } \\
\text { content }\end{array}$ & $\begin{array}{c}\text { Protein } \\
\text { yield }\end{array}$ & $\begin{array}{l}\text { Grain } \\
\text { iron } \\
\text { uptake }\end{array}$ & $\begin{array}{c}\text { Iron utilization } \\
\text { efficiency }\end{array}$ & $\begin{array}{c}\text { Iron harvest } \\
\text { index }\end{array}$ & $\begin{array}{c}\text { Grain } \\
\text { zinc uptake }\end{array}$ & $\begin{array}{c}\text { Zinc utilization } \\
\text { efficiency }\end{array}$ & $\begin{array}{c}\text { Zinc } \\
\text { harvest } \\
\text { index }\end{array}$ \\
\hline Year $(Y)$ & 1 & $32.17^{* *}$ & $201462.26^{* *}$ & $29589.27^{* * *}$ & $126.29^{* * *}$ & $1.56^{\mathrm{ns}}$ & $12490.15^{* *}$ & $6.00^{\text {ns }}$ & $13.14^{\mathrm{ns}}$ \\
\hline Y (R) & 4 & 1.58 & 5671.68 & 2733.65 & 31.63 & 43.53 & 215.20 & 28.14 & 38.98 \\
\hline $\mathrm{pH}(\mathrm{P})$ & 1 & $122.75^{* *}$ & $730361.23^{* *}$ & $460832.06^{* *}$ & $3119.76^{* *}$ & $26.13^{*}$ & $70506.26^{* *}$ & $451.19^{* *}$ & $2.00^{\mathrm{ns}}$ \\
\hline $\operatorname{Iron}(\mathrm{F})$ & 2 & $2.69^{* *}$ & $511619.03^{* *}$ & $356838.14^{* *}$ & $505.02^{* *}$ & $584.20^{* *}$ & $56869.68^{* *}$ & $58.33^{\text {** }}$ & $13.15^{\text {ns }}$ \\
\hline Zinc $(Z)$ & 2 & $7.41^{* * *}$ & $86012.68^{* *}$ & $4071.10^{* *}$ & $0.13^{\mathrm{ns}}$ & $8.69^{\mathrm{ns}}$ & $94798.10^{* * *}$ & $1365.46^{* *}$ & $1441.10^{* * *}$ \\
\hline $\mathrm{Y} \times \mathrm{P}$ & 1 & $0.09^{\text {ns }}$ & $160.90^{\mathrm{ns}}$ & $172.02^{\mathrm{ns}}$ & $113.70^{* *}$ & $26.88^{*}$ & $20.45^{\text {ns }}$ & $13.58^{\mathrm{ns}}$ & $110.11^{* * *}$ \\
\hline $\mathrm{Y} \times \mathrm{F}$ & 2 & $0.01^{\mathrm{ns}}$ & $7190.24^{*}$ & $3939.56^{* *}$ & $11.69^{\mathrm{ns}}$ & $1.61^{\mathrm{ns}}$ & $1098.05^{* *}$ & $1.13^{\mathrm{ns}}$ & $5.04^{\mathrm{ns}}$ \\
\hline $\mathrm{Y} \times \mathrm{Z}$ & 2 & $0.03^{\text {ns }}$ & $2134.89^{\text {ns }}$ & $117.99^{\mathrm{ns}}$ & $0.52^{\mathrm{ns}}$ & $1.97^{\mathrm{ns}}$ & $889.08^{* *}$ & $0.37^{\mathrm{ns}}$ & $2.07^{\mathrm{ns}}$ \\
\hline $\mathrm{P} \times \mathrm{F}$ & 2 & $2.35^{\text {** }}$ & $1011447.26^{* *}$ & $14980.85^{* *}$ & $410.31^{* *}$ & $268.31^{* *}$ & $6076.16^{* *}$ & $44.64^{* *}$ & $71.17^{* * *}$ \\
\hline $\mathrm{P} \times \mathrm{Z}$ & 2 & $0.25^{*}$ & $5619.06^{*}$ & $374.11^{\mathrm{ns}}$ & $4.26^{\mathrm{ns}}$ & $5.10^{\mathrm{ns}}$ & $6754.66^{* *}$ & $12.14^{\mathrm{ns}}$ & $12.86^{\text {ns }}$ \\
\hline $\mathrm{F} \times \mathrm{Z}$ & 4 & $0.02^{\mathrm{ns}}$ & $986.85^{\mathrm{ns}}$ & $349.88^{\mathrm{ns}}$ & $2.01^{\mathrm{ns}}$ & $14.25^{*}$ & $4968.46^{* *}$ & $100.69^{* *}$ & $51.64^{* * *}$ \\
\hline $\mathrm{Y} \times \mathrm{P} \times \mathrm{F}$ & 2 & $0.0003^{\mathrm{ns}}$ & $915.96^{\mathrm{ns}}$ & $533.38^{\mathrm{ns}}$ & $16.05^{*}$ & $0.67^{\mathrm{ns}}$ & $11.32^{\mathrm{ns}}$ & $6.29^{\mathrm{ns}}$ & $0.06^{\mathrm{ns}}$ \\
\hline $\mathrm{Y} \times \mathrm{P} \times \mathrm{Z}$ & 2 & $0.005^{\mathrm{ns}}$ & $424.69^{\mathrm{ns}}$ & $96.99^{\mathrm{ns}}$ & $0.62^{\mathrm{ns}}$ & $1.23^{\mathrm{ns}}$ & $0.50^{\mathrm{ns}}$ & $0.97^{\mathrm{ns}}$ & $3.44^{\mathrm{ns}}$ \\
\hline $\mathrm{Y} \times \mathrm{F} \times \mathrm{Z}$ & 4 & $0.003^{\mathrm{ns}}$ & $59.92^{\mathrm{ns}}$ & $41.19^{\mathrm{ns}}$ & $0.25^{\mathrm{ns}}$ & $3.51^{\mathrm{ns}}$ & $23.40^{\mathrm{ns}}$ & $0.65^{\mathrm{ns}}$ & $2.06^{\mathrm{ns}}$ \\
\hline $\mathrm{P} \times \mathrm{F} \times \mathrm{Z}$ & 4 & $0.022^{\mathrm{ns}}$ & $102.61^{\mathrm{ns}}$ & $237.49^{\mathrm{ns}}$ & $2.60^{\mathrm{ns}}$ & $13.19^{*}$ & $324.23^{\mathrm{ns}}$ & $4.82^{\mathrm{ns}}$ & $21.88^{\text {ns }}$ \\
\hline $\mathrm{Y} \times \mathrm{P} \times \mathrm{F} \times \mathrm{Z}$ & 4 & $0.01^{\mathrm{ns}}$ & $181.86^{\mathrm{ns}}$ & $25.18^{\mathrm{ns}}$ & $0.51^{\mathrm{ns}}$ & $3.75^{\mathrm{ns}}$ & $9.71^{\mathrm{ns}}$ & $0.98^{\text {ns }}$ & $3.76^{\mathrm{ns}}$ \\
\hline Error & 68 & 0.06 & 1562.64 & 321.39 & 5.66 & 5.58 & 174.34 & 7.57 & 11.47 \\
\hline C.V. (\%) & - & 2.39 & 8.71 & 9.41 & 15.21 & 3.77 & 12.74 & 7.71 & 5.96 \\
\hline
\end{tabular}

$\mathrm{ns}, *$ and $* *$ : non significant and significant in $5 \%$ and $1 \%$ probability level, respectively

Table 10. Double interaction of $p H$ of water and iron fertilizer on quantitative parameters of wheat

\begin{tabular}{|c|c|c|c|c|c|c|c|c|}
\hline Interaction & $\begin{array}{l}\text { Grain protein } \\
\text { content }(\%)\end{array}$ & $\begin{array}{c}\text { Protein } \\
\text { yield } \\
\left(\mathrm{kg} \mathrm{ha}^{-1}\right)\end{array}$ & $\begin{array}{c}\text { Grain } \\
\text { iron } \\
\text { uptake }\left({\left.\mathrm{kg} . h a^{-1}\right)}^{-1}\right)\end{array}$ & $\begin{array}{l}\text { Iron utilization } \\
\text { efficiency }\left(\mathrm{kg} \mathrm{kg}^{-1}\right)\end{array}$ & $\begin{array}{c}\text { Iron harvest } \\
\text { index } \\
(\%)\end{array}$ & $\begin{array}{c}\text { Grain } \\
\text { zinc } \\
\text { uptake }\left(\mathrm{kg} \mathrm{ha}^{-1}\right) \\
\end{array}$ & $\begin{array}{c}\text { Zinc utilization } \\
\text { efficiency }(\mathbf{k g} \\
\left.\mathrm{kg}^{-1}\right) \\
\end{array}$ & $\begin{array}{l}\text { Zinc harvest } \\
\text { index }(\%)\end{array}$ \\
\hline $\mathrm{P}_{1} \mathrm{~F}_{1}$ & $8.88 \mathrm{~b}$ & $311.43 \mathrm{e}$ & $53.77 \mathrm{e}$ & $28.74 \mathrm{a}$ & $54.72 \mathrm{~b}$ & $52.71 \mathrm{e}$ & $37.76 \mathrm{a}$ & $58.35 \mathrm{a}$ \\
\hline $\mathrm{P}_{1} \mathrm{~F}_{2}$ & $8.81 \mathrm{~b}$ & $355.60 \mathrm{~d}$ & $109.96 \mathrm{~d}$ & $19.47 \mathrm{~b}$ & $63.75 \mathrm{ab}$ & $73.60 \mathrm{~d}$ & $37.18 \mathrm{a}$ & $55.89 \mathrm{~b}$ \\
\hline $\mathrm{P}_{1} \mathrm{~F}_{3}$ & $8.90 \mathrm{~b}$ & $447.44 \mathrm{c}$ & $211.59 \mathrm{bc}$ & $14.83 \mathrm{c}$ & $67.78 \mathrm{a}$ & $107.97 \mathrm{c}$ & $38.23 \mathrm{a}$ & $55.93 \mathrm{~b}$ \\
\hline $\mathrm{P}_{2} \mathrm{~F}_{1}$ & $10.54 \mathrm{ab}$ & $357.33 \mathrm{~d}$ & $140.45 \mathrm{c}$ & $10.39 \mathrm{~cd}$ & $61.96 \mathrm{ab}$ & $74.15 \mathrm{~d}$ & $31.13 \mathrm{~b}$ & $55.66 \mathrm{~b}$ \\
\hline $\mathrm{P}_{2} \mathrm{~F}_{2}$ & $10.87 \mathrm{ab}$ & $552.38 \mathrm{~b}$ & $247.93 \mathrm{~b}$ & $11.02 \mathrm{~cd}$ & $62.32 \mathrm{ab}$ & $135.60 \mathrm{~b}$ & $34.03 \mathrm{ab}$ & $56.50 \mathrm{ab}$ \\
\hline $\mathrm{P}_{2} \mathrm{~F}_{3}$ & $1.57 \mathrm{a}$ & $698.17 \mathrm{a}$ & $378.87 \mathrm{a}$ & $9.38 \mathrm{~d}$ & $64.93 \mathrm{ab}$ & $177.84 \mathrm{a}$ & $35.74 \mathrm{ab}$ & $58.83 \mathrm{a}$ \\
\hline
\end{tabular}

*: Values within a column followed by same letter are not significantly different at LSD $(\mathrm{P} \leq 0.05)$

$* \mathrm{P}_{1}$ and $\mathrm{P}_{2}$ are $\mathrm{pH}$ of irrigation water including 8.14 and 5 respectively

$\mathrm{F}_{1}, \mathrm{~F}_{2}$ and $\mathrm{F}_{3}$ are iron fertilizer including $0,2.5$ and $5 \mathrm{~g} \mathrm{~L}^{-1}$ respectively 
Table 11. Mean comparison of quantitative parameters of wheat under $p H$ of water, iron and zinc fertilizers treatment

\begin{tabular}{|c|c|c|c|c|c|c|c|c|}
\hline Treatment & $\begin{array}{c}\text { Grain } \\
\text { protein } \\
\text { content }(\%)\end{array}$ & $\begin{array}{l}\text { Protein } \\
\text { yield } \\
\left(\mathrm{kg} \mathrm{ha}^{-1}\right)\end{array}$ & $\begin{array}{c}\text { Grain } \\
\text { iron } \\
\text { uptake } \\
\left(\mathrm{kg} \mathrm{ha}^{-1}\right) \\
\end{array}$ & $\begin{array}{c}\text { Iron utilization } \\
\text { efficiency }(\mathrm{kg} \\
\left.\mathbf{k g}^{-1}\right)\end{array}$ & $\begin{array}{l}\text { Iron harvest } \\
\text { index }(\%)\end{array}$ & $\begin{array}{c}\text { Grain } \\
\text { zinc } \\
\text { uptake } \\
\left(\mathrm{kg} \mathrm{ha}^{-1}\right)\end{array}$ & $\begin{array}{c}\text { Zinc utilization } \\
\text { efficiency (kg } \\
\left.\mathbf{k g}^{-1}\right)\end{array}$ & $\begin{array}{c}\text { Zinc } \\
\text { harvest } \\
\text { index }(\%)\end{array}$ \\
\hline Year & & & & & & & & \\
\hline 2014-15 & $10.47 \mathrm{a}$ & $496.92 \mathrm{a}$ & $206.98 \mathrm{a}$ & $14.56 \mathrm{~b}$ & $62.70 \mathrm{a}$ & $114.40 \mathrm{a}$ & $35.44 \mathrm{a}$ & $57.21 \mathrm{a}$ \\
\hline $2015-16$ & $9.38 \mathrm{~b}$ & $410.53 \mathrm{~b}$ & $173.88 \mathrm{~b}$ & $16.72 \mathrm{a}$ & $62.46 \mathrm{a}$ & $92.89 \mathrm{~b}$ & $35.92 \mathrm{a}$ & $56.51 \mathrm{a}$ \\
\hline LSD 0.05 & 0.09 & 15.18 & 6.88 & 0.91 & 0.91 & 5.07 & 1.06 & 1.30 \\
\hline $\mathrm{pH}$ & & & & & & & & \\
\hline 8.14 & $8.86 \mathrm{~b}$ & $371.49 \mathrm{~b}$ & $125.11 \mathrm{~b}$ & $21.01 \mathrm{a}$ & $62.09 \mathrm{~b}$ & $78.10 \mathrm{~b}$ & $37.72 \mathrm{a}$ & $56.72 \mathrm{a}$ \\
\hline 5 & $10.99 \mathrm{a}$ & $535.96 \mathrm{a}$ & $255.75 \mathrm{a}$ & $10.26 \mathrm{~b}$ & $63.07 \mathrm{a}$ & $129.20 \mathrm{a}$ & $33.64 \mathrm{~b}$ & $57.00 \mathrm{a}$ \\
\hline LSD 0.05 & 0.09 & 18.18 & 6.88 & 0.91 & 0.91 & 5.07 & 1.06 & 1.30 \\
\hline $\mathrm{Fe}$ & & & & & & & & \\
\hline 0 & $19.71 \mathrm{c}$ & $334.38 \mathrm{c}$ & $97.11 \mathrm{c}$ & $12.11 \mathrm{c}$ & $58.34 \mathrm{c}$ & $63.43 c$ & $34.45 \mathrm{~b}$ & $57.01 \mathrm{a}$ \\
\hline $2.5 \mathrm{~g} \mathrm{~L}^{-1}$ & $9.84 \mathrm{~b}$ & $453.99 \mathrm{~b}$ & $178.95 \mathrm{~b}$ & $15.25 \mathrm{~b}$ & $63.04 \mathrm{~b}$ & $104.60 \mathrm{~b}$ & $35.61 \mathrm{~b}$ & $56.20 \mathrm{a}$ \\
\hline $5 \mathrm{~g} \mathrm{~L}^{-1}$ & $10.24 \mathrm{a}$ & $572.80 \mathrm{a}$ & $295.23 \mathrm{a}$ & $19.57 \mathrm{a}$ & $66.36 \mathrm{a}$ & $142.91 \mathrm{a}$ & $36.99 \mathrm{a}$ & $57.38 \mathrm{a}$ \\
\hline LSD 0.05 & 0.11 & 18.59 & 8.43 & 1.12 & 1.11 & 6.21 & 1.29 & 1.59 \\
\hline $\mathrm{Zn}$ & & & & & & & & \\
\hline 0 & $9.46 \mathrm{c}$ & $404.42 \mathrm{c}$ & $180.01 \mathrm{c}$ & $15.62 \mathrm{a}$ & $63.11 \mathrm{a}$ & $49.97 \mathrm{c}$ & $42.53 \mathrm{a}$ & $49.65 \mathrm{c}$ \\
\hline $2.5 \mathrm{~g} \mathrm{~L}^{-1}$ & $9.96 \mathrm{~b}$ & $454.58 \mathrm{~b}$ & $190.01 \mathrm{~b}$ & $15.71 \mathrm{a}$ & $62.48 \mathrm{a}$ & $108.75 \mathrm{~b}$ & $33.92 \mathrm{~b}$ & $59.45 \mathrm{~b}$ \\
\hline $5 \mathrm{~g} \mathrm{~L}^{-1}$ & $10.37 \mathrm{a}$ & $502.17 \mathrm{a}$ & $201.27 \mathrm{a}$ & $15.60 \mathrm{a}$ & $62.15 \mathrm{a}$ & $152.22 \mathrm{a}$ & $30.59 \mathrm{c}$ & $61.48 \mathrm{a}$ \\
\hline LSD 0.05 & 0.11 & 18.59 & 8.43 & 1.12 & 1.11 & 6.21 & 1.29 & 1.59 \\
\hline
\end{tabular}

*: Values within a column followed by same letter are not significantly different at LSD $(\mathrm{P} \leq 0.05)$ 
At the triple interactions of year, water acidity, and iron consumption, only the iron utilization efficiency demonstrated a significant difference of $5 \%$ in the probability level. Moreover, in the triple interaction of water acidity, iron, and zinc foliar application, it was found that the iron harvest index and the straw zinc content statistically revealed significant differences at $1 \%$ and $5 \%$ probability levels (Table 9).

At the double interaction of water acidity and the iron foliar application, the greatest grain protein content $\left(11.57 \%\right.$ ) was observed at a $\mathrm{pH}$ value $=5$, with a $5 \mathrm{~g} \mathrm{~L}^{-1}$ zinc foliar application. The least grain protein content $(8.88,8.81$, and $8.90 \%)$ was observed at a $\mathrm{pH}$ value $=8.14$ in the all the three zinc fertilizer levels (Table 10). Moreover, the double interaction of water acidity and zinc foliar application revealed that the maximum grain protein contents $(11.06$ and $11.50 \%)$ were obtained at a $\mathrm{pH}$ value $=5$, with 2.5 and $5 \mathrm{~g} \mathrm{~L}^{-1}$ zinc foliar applications. The minimum grain protein content $(8.49 \%)$ was observed at a $\mathrm{pH}$ value $=8.14$ and control treatment (Table 5). At the double interaction of the year and the iron foliar application, the highest protein yield (629.69 $\mathrm{kg} \mathrm{ha}^{-1}$ ) was produced in the first year for $5 \mathrm{~g} \mathrm{~L}^{-1}$ iron consumption. The least protein yield $\left(305.72 \mathrm{~kg} \mathrm{ha}^{-1}\right.$ ) was obtained in the second year for control treatment (Table 10). Moreover, at the double interaction of water acidity and iron foliar application, the greatest protein yield $\left(698.17 \mathrm{~kg} \mathrm{ha}^{-1}\right)$ was produced for a $\mathrm{pH}$ value $=5$ and $5 \mathrm{gL}^{-1}$ iron consumption. The least protein yield $\left(335.35 \mathrm{~kg} \mathrm{ha}^{-1}\right)$ was observed at a $\mathrm{pH}$ value $=8.14$ and control treatment (Table 5) .

The mean comparison of the treatments showed that the grain iron uptake was increased in $5 \mathrm{~g} \mathrm{~L}^{-1}$ zinc foliar application compared to other levels (Table 11). At the double interaction of the year and the iron foliar application, the most grain iron uptake was obtained in the first year for $5 \mathrm{~g} \mathrm{~L}^{-1}$ iron consumption $\left(323.45 \mathrm{~kg} \mathrm{ha}^{-1}\right)$. The least grain iron uptake $\left(105.11 \mathrm{~kg} \mathrm{ha}^{-1}\right)$ was recorded in the second year for the control treatment (Table 12). In addition, at the double interaction of water acidity and iron foliar application, the highest grain iron uptake $\left(378.87 \mathrm{~kg} \mathrm{ha}^{-1}\right)$ was observed at a $\mathrm{pH}$ value $=5$, with a $5 \mathrm{~g} \mathrm{~L}^{-1}$ iron foliar application, but the least grain iron uptake (335.35 $\mathrm{kg} \mathrm{ha}^{-1}$ ) was observed at a $\mathrm{pH}$ value $=8.14$ and control treatment (Table 5).

Table 12. Double interaction of year and iron fertilizer on qualitative traits of wheat

\begin{tabular}{c|c|c|c|c}
\hline Interaction & $\begin{array}{c}\text { Protein yield } \\
\left(\mathbf{k g ~ h a}^{-\mathbf{~}}\right)\end{array}$ & $\begin{array}{c}\text { Grain iron content } \\
(\mathbf{\%})\end{array}$ & $\begin{array}{c}\text { Grain iron uptake } \\
\left(\mathbf{k g ~ h a} \mathbf{~}^{\mathbf{1}} \mathbf{)}\right.\end{array}$ & $\begin{array}{c}\text { Grain zinc uptake } \\
\left(\mathbf{k g ~ h a}^{\mathbf{- 1}} \mathbf{)}\right.\end{array}$ \\
\hline $\mathrm{Y}_{1} \mathrm{~F}_{1}$ & $363.04 \mathrm{bc}$ & $29.90 \mathrm{c}$ & $105.11 \mathrm{~d}$ & $68.60 \mathrm{c}$ \\
$\mathrm{Y}_{1} \mathrm{~F}_{2}$ & $498.02 \mathrm{ab}$ & $39.56 \mathrm{~b}$ & $192.38 \mathrm{bc}$ & $115.48 \mathrm{~b}$ \\
$\mathrm{Y}_{1} \mathrm{~F}_{3}$ & $629.69 \mathrm{a}$ & $55.20 \mathrm{a}$ & $323.45 \mathrm{a}$ & $159.12 \mathrm{a}$ \\
$\mathrm{Y}_{2} \mathrm{~F}_{1}$ & $305.72 \mathrm{c}$ & $27.14 \mathrm{c}$ & $89.11 \mathrm{e}$ & $58.26 \mathrm{~d}$ \\
$\mathrm{Y}_{2} \mathrm{~F}_{2}$ & $409.96 \mathrm{~b}$ & $36.48 \mathrm{~b}$ & $165.51 \mathrm{c}$ & $93.72 \mathrm{bc}$ \\
$\mathrm{Y}_{2} \mathrm{~F}_{3}$ & $515.92 \mathrm{ab}$ & $49.82 \mathrm{ab}$ & $267.01 \mathrm{~b}$ & $126.69 \mathrm{ab}$ \\
\hline
\end{tabular}

*: Values within a column followed by same letter are not significantly different at $\mathrm{LSD}(\mathrm{P} \leq 0.05)$

$Y_{1}$ and $Y_{2}$ are experiment period including 2014-15 and 2015-16 years respectively

$\mathrm{F}_{1}, \mathrm{~F}_{2}$ and $\mathrm{F}_{3}$ are iron fertilizer including $0,2.5$ and $5 \mathrm{~g} \mathrm{~L}^{-1}$ respectively

Moreover, at the triple interaction of the year, water acidity, and the iron foliar application, the greatest iron utilization efficiency was produced in both years for a $\mathrm{pH}$ value $=8.14$ and control treatment. The least iron utilization efficiency was, however, calculated in both years for a $\mathrm{pH}$ value $=5$, with $5 \mathrm{~g} \mathrm{~L}^{-1}$ iron foliar application (Figure 1). In addition, at a triple interaction of water acidity, iron, and zinc foliar application, 
the largest iron harvest index was recorded at a $\mathrm{pH}$ value $=8.14$, with $5 \mathrm{~g} \mathrm{~L}^{-1}$ iron foliar application, and all the three zinc consumption levels $(67.54,66.57$, and $69.24 \%$ ) respectively. The least iron harvest index $(52.23 \%)$ was obtained at a $\mathrm{pH}$ value $=8.14$ and iron control treatment with $5 \mathrm{~g} \mathrm{~L}^{-1}$ zinc foliar application (Table 8).

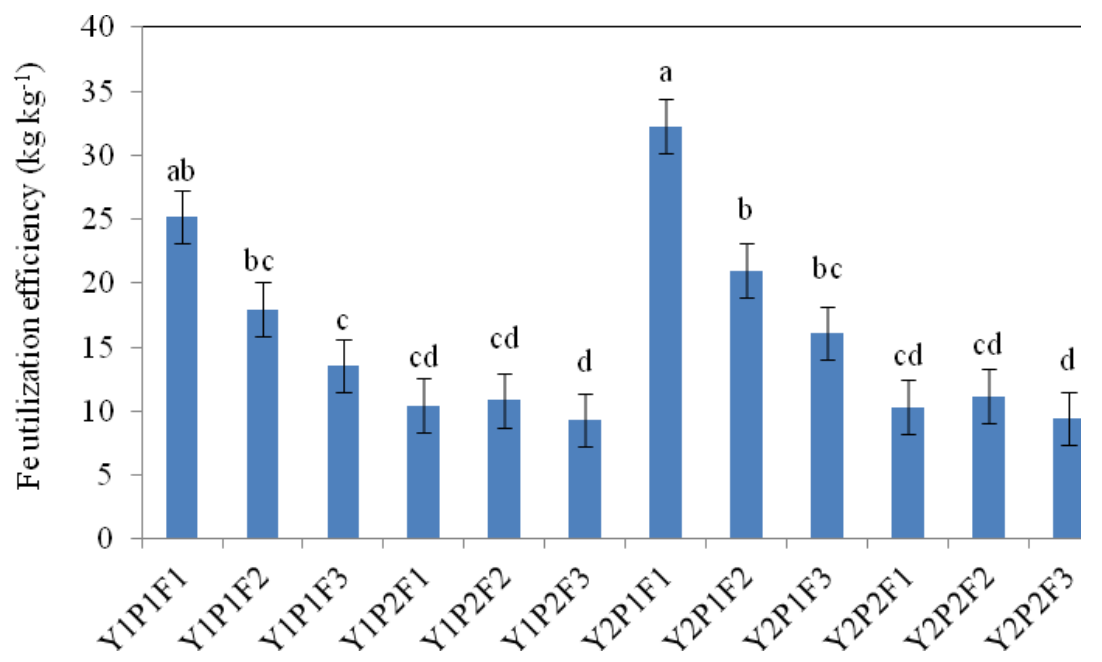

Figure 1. Triple interaction of year, $p H$ of water and iron fertilizer on iron utilization efficiency $Y_{1}$ and $Y_{2}$ are experiment period including 2014-15 and 2015-16 years respectively

$* P_{1}$ and $P_{2}$ are $p H$ of irrigation water including 8.14 and 5 respectively $F_{1}, F_{2}$ and $F_{3}$ are iron fertilizer including $0,2.5$ and $5 \mathrm{~g} \mathrm{~L}^{-1}$ respectively

According to the double interaction of year and water acidity, the highest grain zinc uptake $\left(159.12 \mathrm{~kg} \mathrm{ha}^{-1}\right)$ was recorded in the first year with $5 \mathrm{~g} \mathrm{~L}^{-1}$ iron consumption, but the least grain zinc uptake $\left(68.60 \mathrm{~kg} \mathrm{ha}^{-1}\right)$ was obtained in the first year for control treatment (Table 12). At the double interaction of water acidity and iron consumption, the greatest grain zinc uptake $\left(177.84 \mathrm{~kg} \mathrm{ha}^{-1}\right)$ was recorded at $\mathrm{pH}$ value $=5$, with $5 \mathrm{~g}$ $\mathrm{L}^{-1}$ iron usage, but the least grain zinc uptake was observed at $\mathrm{pH}$ value $=8.14$ for the control treatment (Table 10). Moreover, at the double interaction of water acidity and the zinc foliar application, the highest grain zinc uptake $\left(190.94 \mathrm{~kg} \mathrm{ha}^{-1}\right)$ was calculated at $\mathrm{pH}$ value $=5$, with $5 \mathrm{~g} \mathrm{~L}^{-1}$ zinc consumption; but the least grain zinc uptake was recorded at $\mathrm{pH}$ value $=8.14$ for the control treatment (Table 5). In addition, at the double interaction of the iron and zinc foliar application, the maximum grain zinc uptake $\left(208.23 \mathrm{~kg} \mathrm{ha}^{-1}\right.$ ) was produced for $5 \mathrm{~g} \mathrm{~L}^{-1}$ iron and zinc consumption, but the least grain zinc uptake $\left(32.16 \mathrm{~kg} \mathrm{ha}^{-1}\right.$ ) was observed for the control treatment (Table 13). According to the double interaction of water acidity and the iron foliar application, the greatest zinc utilization efficiency was calculated at a $\mathrm{pH}$ value $=8.14$ for all the three iron consumption levels equaling $37.76,37.18$, and $38.23 \mathrm{~kg} \mathrm{ka}^{-1}$, respectively. The least zinc utilization efficiency $\left(31.13 \mathrm{~kg} \mathrm{~kg}^{-1}\right)$ was observed at $\mathrm{pH}$ value $=5$ for the control treatment (Table 10). At the double interaction of iron and zinc foliar application, the maximum zinc utilization efficiency $\left(47.11 \mathrm{~kg} \mathrm{~kg}^{-1}\right)$ was obtained for the iron control treatment with $5 \mathrm{~g} \mathrm{~L}^{-1}$ zinc consumption. The least zinc utilization efficiency (30.55 kg kg-1) was obtained for $2.5 \mathrm{~g} \mathrm{~L}^{-1}$ iron usage with $5 \mathrm{~g} \mathrm{~L}^{-1}$ zinc consumption, and $5 \mathrm{~g} \mathrm{~L}^{-1}$ iron and zinc consumption (Table 13). 
Table 13. Double interaction of iron and zinc fertilizers on quantitative parameters of wheat

\begin{tabular}{c|c|c|c|c}
\hline Interaction & $\begin{array}{c}\text { Iron harvest } \\
\text { index (\%) }\end{array}$ & $\begin{array}{c}\text { Grain zinc } \\
\text { uptake }\left(\mathbf{k g ~ h a}^{-\mathbf{1}}\right)\end{array}$ & $\begin{array}{c}\text { Zinc utilization } \\
\left.\text { efficiency (kg kg } \mathbf{~}^{-1}\right)\end{array}$ & $\begin{array}{c}\text { Zinc harvest } \\
\text { index (\%) }\end{array}$ \\
\hline $\mathrm{F}_{1} \mathrm{Z}_{1}$ & $60.01 \mathrm{ab}$ & $32.16 \mathrm{e}$ & $38.01 \mathrm{~b}$ & $48.13 \mathrm{c}$ \\
$\mathrm{F}_{1} \mathrm{Z}_{2}$ & $58.09 \mathrm{ab}$ & $64.40 \mathrm{~cd}$ & $33.79 \mathrm{c}$ & $59.36 \mathrm{ab}$ \\
$\mathrm{F}_{1} \mathrm{Z}_{3}$ & $56.91 \mathrm{~b}$ & $93.73 \mathrm{c}$ & $31.54 \mathrm{~cd}$ & $63.54 \mathrm{a}$ \\
$\mathrm{F}_{2} \mathrm{Z}_{1}$ & $63.33 \mathrm{a}$ & $50.63 \mathrm{~d}$ & $42.46 \mathrm{ab}$ & $48.25 \mathrm{bc}$ \\
$\mathrm{F}_{2} \mathrm{Z}_{2}$ & $63.33 \mathrm{a}$ & $108.47 \mathrm{bc}$ & $33.81 \mathrm{~cd}$ & $59.49 \mathrm{ab}$ \\
$\mathrm{F}_{2} \mathrm{Z}_{3}$ & $62.46 \mathrm{a}$ & $154.70 \mathrm{~b}$ & $30.55 \mathrm{~d}$ & $60.84 \mathrm{ab}$ \\
$\mathrm{F}_{3} \mathrm{Z}_{1}$ & $65.99 \mathrm{a}$ & $67.10 \mathrm{~cd}$ & $47.11 \mathrm{a}$ & $52.57 \mathrm{~b}$ \\
$\mathrm{~F}_{3} \mathrm{Z}_{2}$ & $66.01 \mathrm{a}$ & $153.38 \mathrm{~b}$ & $34.16 \mathrm{c}$ & $59.50 \mathrm{ab}$ \\
$\mathrm{F}_{3} \mathrm{Z}_{3}$ & $67.07 \mathrm{a}$ & $208.23 \mathrm{a}$ & $29.69 \mathrm{~d}$ & $60.07 \mathrm{ab}$ \\
\hline
\end{tabular}

*: Values within a column followed by same letter are not significantly different at $\operatorname{LSD}(\mathrm{P} \leq 0.05)$

$\mathrm{F}_{1}, \mathrm{~F}_{2}$ and $\mathrm{F}_{3}$ are iron fertilizer including $0,2.5$ and $5 \mathrm{~g} \mathrm{~L}^{-1}$ respectively

$\mathrm{Z}_{1}, \mathrm{Z}_{2}$ and $\mathrm{Z}_{3}$ are zinc fertilizer including $0,2.5$ and $5 \mathrm{~g} \mathrm{~L}^{-1}$ respectively

According to the double interaction of year and water acidity, the zinc harvest index in the first year for both the $\mathrm{pH}$ levels were 56.06 and $58.36 \%$, and in the second year, both the $\mathrm{pH}$ levels were 57.39 and $55.64 \%$ (Table 7). At the double interaction of water acidity and iron foliar application, the highest zinc harvest index was recorded at the $\mathrm{pH}$ value $=8.14$ for the control treatment $(58.35 \%)$ and $\mathrm{pH}$ value $=5$, with $5 \mathrm{~g} \mathrm{~L}^{-1}$ iron consumption. The least zinc harvest index was calculated at a $\mathrm{pH}$ value $=8.14$ for 2.5 and $5 \mathrm{~g} \mathrm{~L}^{-1}$ (55.89 and 55.93\%), and $\mathrm{pH}$ value $=5$ and control treatment $(55.56 \%)$, respectively (Table 10). Moreover, at the double interaction of iron and zinc foliar application, the greatest zinc harvest index (63.54\%) was observed in the iron control treatment with $5 \mathrm{~g} \mathrm{~L}^{-1}$ zinc consumption. The minimum zinc harvest index $(48.13 \%)$ was recorded in the control treatment (Table 13). Furthermore, at double interaction of year and zinc foliar application, grain zinc uptake in both years was increased with 2.5 and $5 \mathrm{~g} \mathrm{~L}^{-1}$ zinc consumption compared to control treatment that the highest amount was observed with $5 \mathrm{~g} \mathrm{~L}^{-1}$ zinc consumption (Figure 2).

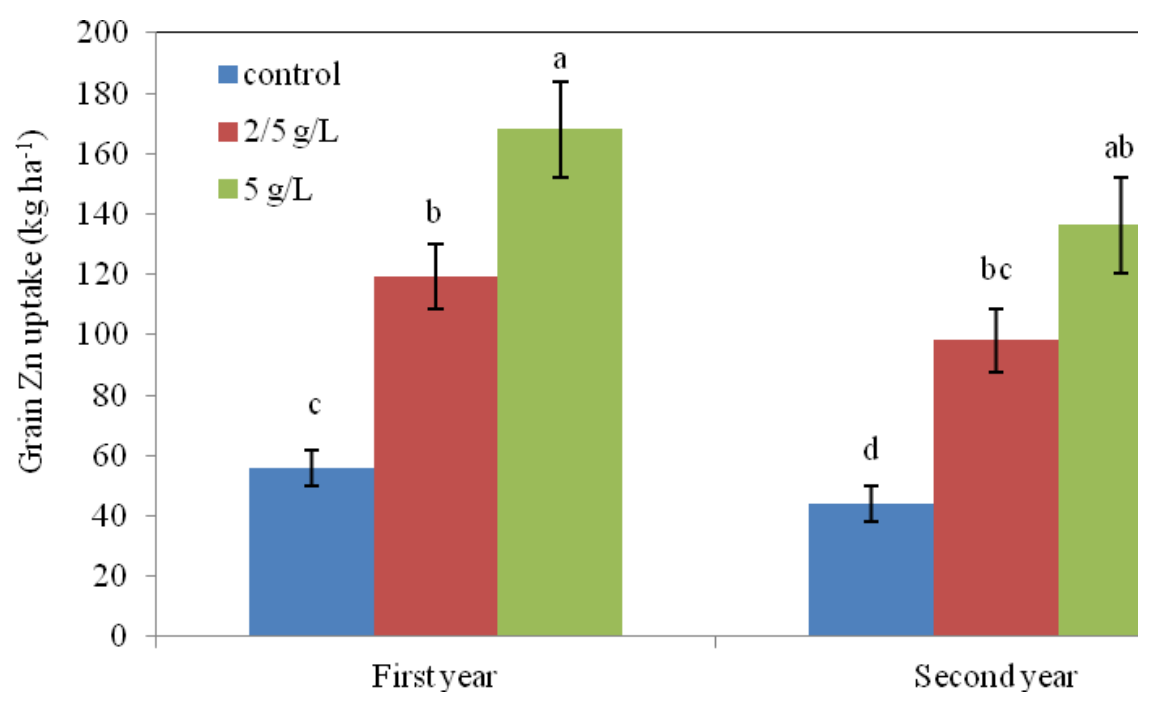

Figure 2. Double interaction of year and zinc fertilizer on grain zinc uptake 


\section{Discussion}

Low soil reaction is associated with a number of adverse chemical and biological properties that cause problems for plant growth. Chemical $\mathrm{pH}$-dependent changes limit the accessibility of essential elements and increase the availability of toxic metals, such as aluminum and manganese (Holier and Rutherglen, 2005). Zinc seems to increase plant height by increasing the $\mathrm{CO}_{2}$ assimilation, increasing photosynthesis (Thalooth et al., 2006), and increasing the water use efficiency (Khan, 2004). Mohammad et al. (2000) reported that zinc and iron application with different methods increased grain yield in comparison to control, and using zinc by the spraying method, maximum grain yield, and zinc concentration were obtained in the grain; using the soil and the spraying method recorded the highest grain yield and grain iron content. The presence of a factor, such as acidity, which restricts access to nutrients in the soil, reduces the expected use of fertilizers. Under these conditions, the nutrient elements for plants can be provided by the use of a leaf (Altındişli et al., 2004). Foliar application is the spraying of nutrients on leaves and stems, and their absorption from these places (Kapoor et al., 2003). Leaf consumption can guarantee plant access to nutrients to achieve high yields. Ecologically, foliar fertilization is more acceptable because lower quantities of nutrients are provided for quick consumption by the plant (Stampar et al., 2008).

There is a negative interaction between iron intake and zinc concentration in the grain. When the amount of zinc absorbed by the soil is low, it is possible that the iron application intensifies the zinc deficiency. The absorption of elements such as iron, zinc, magnesium, phosphorus, and molybdenum depends on the acidity of the soil. In addition to the above elements, the nitrogen uptake by the root also depends on the acidity of the soil; thus nitrogen uptake in alkaline soils has a higher limitation than in acidic soils (Nyachiro and Briggs, 1994). Iran's irrigated soils have severe micronutrient deficiencies, especially zinc and iron, for reasons such as calcareous soils, uncarbonated irrigation water, low organic matter, and excessive consumption of phosphate fertilizers. Sadana et al. (2006) concluded that iron soil and foliar application increased the growth and the yield of wheat compared to control treatment, and the amount of iron in grains and straw increased. According to some researchers, zinc foliar application increases photosynthesis, promotes plant growth, improves nitrogen uptake, grain protein and grain yield, and zinc deficiency leads to poor grain formation (Thalooth et al., 2006). In other research for rice plant, the most zinc content in grain and straw were produced with $40 \mathrm{~kg}$ zinc per hectare (Yadi and Dastan, 2012). The reduction of wheat yield in alkaline acidity has been attributed to many factors. In addition, in alkaline acidity, the plant's access to nitrogen compounds is very low; reducing the amount of nitrogen utilized by soil is the main factor for reducing the grain yield. The acidity of alkali causes changes in the permeability of the membrane of the rooted cells and prevents the entry of elements such as iron and zinc into the plant (Nyachiro and Briggs, 1994).

\section{Conclusion}

The application of micronutrient fertilizers affected the yield and the absorption of iron and zinc on wheat and increased the net production. An increase in acidity leads to the precipitation of nutrients (reduction of solubility) and a decrease in the soil's ability to absorb the elements; this is why the plant consumes more energy and decreases the $\mathrm{pH}$ of the environment surrounding the root of the plant so that it would be able to 
absorb the necessary nutrients. Therefore, the energy that is consumed for growth and production under normal conditions is consumed for absorbing the necessary nutrients at higher acidities. On the other hand, a severe reduction of acidity is very harmful because as the solubility of the elements increase, the plant becomes more toxic, which is in itself a limiting factor and the plant copes with the oxidative stress by consuming energy. Therefore, this research should be conducted in the other region to determine the best finding for extensions.

\section{REFERENCES}

[1] Altındişli, A., Irget, M. E., Kalkan, H., Kara, S., Oktay, M. (2004): Effect of foliar applied KNO3 on yield, quality and leaf nutrients of Carignane and Colombard wine grapes. - In: Anac, D., Martin-Prével, P. (eds.) Improved Crop Quality by Nutrient Management, pp: 103-106.

[2] Borrill, P., James, M., Connorton, J., Balk, A. J., Miller, D., Cristobal, U. (2014): Biofortification of wheat grain with iron and zinc: integrating novel genomic resources and knowledge from model crops. - Front Plant Science 5(53): doi:10.3389/fpls.2014.00053.

[3] Cakmak, I. (2008): Enrichment of cereal grains with zinc: Agronomic or genetic biofortification? - Plant Soil 302: 1-17

[4] Cakmak, I., Ozkan, H., Braun, H. J., Welch, R. M., Romheld, V. (2000): Zinc and iron concentrations in seeds of wild, primitive, and modern wheats. - Food Nutr. Bull. 2: 401403.

[5] Distelfeld, A., Cakmak, I., Peleg, Z., Ozturk, L., Yazici, A. M., Budak, H. (2007): Multiple QTL-effects of wheat Gpc-B1 locus on grain protein and micronutrient concentrations. - Physiol. Plant. 129: 635-643.

[6] Dobermann, A. (2005): Nitrogen Use Efficiency - State of the Art. IFA International Workshop on Enhanced - Efficiency Fertilizers Frankfurt, Germany, 28-30 June.

[7] Fan, X., Lin, F., Kumar, D. (2004): Fertilization with a new type of coated urea. Evaluation for nitrogen efficiency and yield in winter wheat. - Journal of Plant Nutrition 25: 853-865.

[8] FAO. (2016): Faostat-Trade/Crops and livestock products, available in http://faostat3.fao.org/browse/T/TP/E[15 April 2016]

[9] Hollier, C., Rutherglen, M. R. (2005): Acid soils. - Agricultural Notes, AG 1182.

[10] Kapoor, R., Giri, B., Mukerji, G. (2003): Mycorrhization of coriander (Coriandrum sativum L.) to enhance the concentration and quality of essential oil. - Journal of the Science of Foot and Agriculture 82(4): 339-342.

[11] Khan, H. R., McDonald, G. K., Rengel, Z. (2004): Zinc fertilization improves water use efficiency, grain yield and seed Zn content in chickpea. - Plant Soil 249: 389-400.

[12] Martre, P., Porter, J. R., Jamieson, P. D., Triboi, E. (2003): Modeling Grain Nitrogen Accumulation and Protein Composition to Understand the Sink/Source Regulations of Nitrogen Remobilization for Wheat. - Plant Physiology 133: 1959-1967.

[13] Ministry of Jihad-e-Agriculture of Iran (2016): Annual Agricultural Statics. www.maj.ir

[14] Mohammad, M. J., Pan, W. L., Kennedy, A. C. (2000): Wheat responses to Vesicular Arbuscular Mycorrhizal fungi inoculation of soils from eroded to posequence. - Journal of American Soil Science Society 59: 1086-1090.

[15] Monasterio, I., Graham, R. D. (2000): Breeding for trace minerals in wheat. - Food Nutr. Bull. 21: 392-396.

[16] Murray, C. J. L., Lopez, A. D. (2013): Measuring the global burden of disease. - N. Engl. J. Med. 369: 448-457. 
[17] Nyachiro, J. M., Briggs, K. G. (1994): Seedling root response of some Kenyan bread wheat cultivars grown in acid nutrient culture solution containing aluminum. - Plant and Soil 158: 141-144.

[18] Pazouki, T. M., Ajam Noroui, H., Ghanbari Malidareh, A., Dadashi, M. R., Dastan, S. (2017): Energy and $\mathrm{CO}_{2}$ emission assessment of wheat (Triticum aestivum L.) production scenarios in central areas of Mazandaran province, Iran. - Applied Ecology and Environmental Research 15(4): 143-161.

[19] Sadana, U. S., Nayyar, V. K., Takker, P. N. (2006): Response of Wheat grain grown on manganese sulphate application. - Fertilizer News 36(3): 55-57.

[20] Samonte, S. O., Wilson, L. T., Medley, J. C., Pinson, Sh. R. M., McClung, A. M., Lales, J. S. (2006): Nitrogen Utilization Efficiency: Relationships with grain yield, grain protein, and yield-related traits in rice. - Agronomy Journal 98: 168-176.

[21] Stampar, F., Hudina, M., Dolenc, K., Usenik, V. (2008): Influence of foliar fertilization on yield quantity and quality of apple (Malus domestica borkh.). - In: Anac, D., MartinPrével, P. (eds.) Improved crop quality by nutrient management, 91-94.

[22] Thalooth, M., Tawfik, M., Magda Mohamed, H. (2006): A comparative study on the effect of foliar application of zinc, potassium and magnesium on growth, yield and some chemical constituents of mungbean plants growth under Water stress conditions. - World J. Agric. Sci. 2: 37-46.

[23] Uauy, C., Distelfeld, A., Fahima, T., Blechl, A., Dubcovsky, J. (2006): A NAC gene regulating senescence improves grain protein, zinc, and iron content in wheat. - Science 314: 1298-1301.

[24] Uphoff, N. (2012): Supporting food security in the $21^{\text {st }}$ century through resourceconserving increase in agricultural production. - Agriculture and Food Security 1: 18-30.

[25] Wessells, K. R., Brown, K. H. (2012): Estimating the global prevalence of zinc deficiency: results based on zinc availability in national food supplies and the prevalence of stunting. - PLoS ONE 7: e50568.

[26] WHO (2008): Worldwide Prevalence of Anaemia 1993-2005. - In: de Benoist, B., McLean, E., Egli, I., Cogswell, M. (eds.) WHO Global Database on Anaemia. Geneva: World Health Organization Press.

[27] WHO (2009): Global Health Risks. Mortality Burden of Disease Attributable to Selected Major Risks. Available at: http://www.who.int/ healthinfo/ global_burden_disease/ GlobalHealthRisks_report_annex.pdf (accessed October 30, 2013).

[28] Wissuwa, M., Gamat, G., Ismail, A. M. (2008): Is root growth under phosphorus deficiency affected by source or sink limitation. - Journal of Experimental Botany 56: 1943-1950.

[29] Yadi, R., Dastan, S. (2012): Role of zinc fertilizer on grain yield and some qualities parameters in Iranian rice genotypes. - Annals of Biological Research 3(9): 4519-4527.

[30] Yadi, R., Ebrahimi, M., Dastan, S. (2016): Effect of seed rate in different sowing dates on grain yield and yield components of wheat in Iran. - International Journal of Tropical Medicine 11 (6): 208-213.

[31] Zhang,Y., Shi, R., Rezaul, K. M., Zhang, F., Zou, C. (2010): Iron and zinc concentrations in grain and flour of winter wheat as affected by foliar application. - Journal of Agric Food Chemistry 8(23): 12268-12274. 